\title{
PENGARUH SISTEM PENGELOLAAN AIR DAN VARIETAS TERHADAP HASIL PADI DAN EMISI GAS RUMAH KACA DI LAHAN TADAH HUJAN
}

\author{
${ }^{1}$ Ali Pramono*, ${ }^{2}$ Terry Ayu Adriani dan ${ }^{3}$ Prihasto Setyanto \\ 1,2,3 Balai Penelitian Lingkungan Pertanian Jln Raya Jakenan-Jaken \\ Km 5 Pati Jawa Tengah *Penulis korespondensi Email : \\ ali_pramono@yahoo.com
}

Diterima : 9 April 2016

Disetujui : 15 Juli 2016

\begin{abstract}
Intisari
Lahan sawah berperan penting dalam keamanan pangan nasional secara berkelanjutan, namun produksi padi di lahan sawah berkontribusi terhadap emisi gas rumah kaca secara signifikan terutama metana $\left(\mathrm{Ch}_{4}\right)$. Beberapa usaha yang dilakukan untuk mengurangi emisi GRK di lahan sawah telah dilakukan, diantaranya adalah pengelolaan air dan pupuk, penggunaan varietas padi yang mengemisi GRK rendah. Tujuan utama penelitian ini adalah untuk mengetahui pengaruh sistem pengelolaan air dan varietas padi terhadap hasil padi dan emisi GRK. Penelitian dilakukan di Kebun Percobaan Balingtan, Pati-Jawa Tengah pada bulan MaretJuni 2016. Penelitian menggunakan rancangan split plot dengan faktor I pengelolaan air (A1=Tergenang 5 $\mathrm{cm}$ dan A2=Alternate Wetting and Drying/AWD), faktor II varietas padi (V1=Ciherang, V2=Inpari 30, V3= IPB3S), dan ulangan 3 kali. Pengukuran gas rumah kaca dilakukan dengan metode sungkup tertutup (close chamber). Parameter yang diamati fluks $\mathrm{CH}_{4}$ dan $\mathrm{N}_{2} \mathrm{O}$, Eh dan $\mathrm{pH}$, tinggi muka air tanah, tinggi tanaman dan jumlah anakan, serta hasil dan komponen hasil padi. Hasil penelitian menunjukkan bahwa hasil padi tertinggi terdapat pada perlakuan A2V1 (AWD dengan varietas Ciherang) sebesar 3,26 ton GKG/ha. Emisi $\mathrm{CH}_{4}$ terendah dihasilkan pada perlakuan A2V1 (AWD dengan varietas padi Ciherang). Emisi $\mathrm{N}_{2} \mathrm{O}$ terendah dihasilkan pada perlakuan A2V3 (AWD dengan varietas IPB3S). Emisi GRK tertinggi terdapat pada perlakuan A1V3 (tergenang dengan varietas IPB3S). Emisi GRK terendah terdapat pada A2V1 (perlakuan AWD dengan varietas Ciherang. Indeks emisi terendah terdapat pada perlakuan A2V2 (perlakuan AWD dengan varietas Inpari 30). Perlakuan AWD dapat menurunkan emisi GRK pada varietas padi Ciherang, Inpari 30 dan IPB3S masing-masing sebesar 42\%, 46\%, dan 30\% dibandingkan dengan kondisi tergenang.
\end{abstract}

Kata kunci : Emisi gas rumah kaca, Lahan tadah hujan, Pengelolaan air, Varietas.

\begin{abstract}
Rice field is an important role in sustainable national food security, rice production contributes to greenhouse gas emissions significantly, especially methane (Ch4). Some of these efforts to reduce GHG emissions in the paddy field has been done, such as water and fertilizer management, using low methane emission of rice varieties. The main objective of this study was to determine the effect of water management systems and rice varieties on grain yield and GHG emissions. The study was conducted at the Experimental Research Station of IAERI, Pati, Central Java in March to June 2016. The study design was a split plot with the factor I water management $(A 1=$ Flooded $5 \mathrm{~cm}$ and $A 2=$ Alternate Wetting and Drying $/ A W D)$, factor II rice varieties $(V 1=$ Ciherang, V2 = Inpari 30, V3 $=I P B 3 S)$, and replicated 3 times. GHG measurement was conducted using a closed chamber. The parameters were observed mainly $\mathrm{CH}_{4}$ and $\mathrm{N}_{2} \mathrm{O}$ fluxes, Eh and $\mathrm{pH}$, water level surface, plant height and tiller number, grain and yield components. The results showed that the highest grain yields was A2VI

treatment (AWD and Ciherang variety) amounted to 3.26 tons ha. The lowest of $\mathrm{CH}_{4}$ emissions was A2VI treatment ( $A W D$ and Ciherang variety). $\mathrm{N}_{2} \mathrm{O}$ emissions produced the lowest in treatment $A 2 \mathrm{~V} 3$ ( $A W D$ and IPB3S variety). The highest of GHG emissions was AlV3 treatment (continuous flooding and IPB3S variety). The lowest of GHG emissions was A2V1 treatment (AWD and Ciherang variety). The lowest emissions index was A2V2 treatment ( $A W D$ and Inpari 30 variety). AWD treatment could reduce GHG emissions of Ciherang, Inpari 30 and IPB 3 S rice varieties by $42 \%, 46 \%$, and $30 \%$ compared to continuous flooding, respectively.
\end{abstract}

Keywords: Greenhouse gas emissions, Rainfed lowland area, Rice varieties, Water management 


\section{PENDAHULUAN}

Lahan sawah berperan penting dalam keamanan pangan nasional secara berkelanjutan. Produksi padi di lahan sawah berkontribusi terhadap emisi gas rumah kaca secara signifikan terutama metana $\left(\mathrm{CH}_{4}\right)$ sebesar $12 \%$ dari total $\mathrm{CH}_{4}$ antropogenik (IPCC, 2007). Diperkirakan, emisi $\mathrm{CH}_{4}$ dari lahan sawah berkisar antara 39 hingga $112 \mathrm{Tg} \mathrm{CH}_{4}$ per tahun (Denman dkk, 2007). Meningkatnya emisi $\mathrm{CH}_{4}$ disebabkan karena kebutuhan beras semakin meningkat dengan bertambahnya penduduk dunia, hal ini mendorong produksi pangan terutama padi semakin meningkat dari dekade ke dekade (Wang $d k k, 2000$ ).

$\mathrm{Ch}_{4}$ diemisikan dari lahan sawah ke atmosfer melalui tiga cara yaitu ebolusi, difusi dan transport yang dimediasi tanaman padi (Dubey $d k k$, 2005).Emisi $\mathrm{CH}_{4}$ dari lahan sawah disebabkan oleh produksi $\mathrm{CH} 4$ oleh metanogen. Fluks $\mathrm{CH}_{4}$ di lahan sawah dipengaruhi oleh beberapa faktor seperti praktek pengelolaan air, pemupukan organik dan anorganik, sifat fisikokimia dan geokimia tanah, suhu tanah dan udara, komposisi dan aktivitas mikroorganisme tanah, dan karakter fisiologi tanaman masingmasing kultivar padi (Bodelier dkk, 2000). Varietas padi berpengaruh terhadap emisi $\mathrm{CH}_{4}$ karena tanaman padi memediasi transportasi $\mathrm{CH}_{4}$ dan $\mathrm{O}_{2}$ melalui jaringan aerenkim (Butterbach-Bahl dkk, 1997; Aulakh $d k k, 2000)$ dan menyediakan substrat bagi metanogen dan bakteri metanotrof melalui eksudat akar dan dekomposisi akar tanaman yang telah mati (Kerdchoechuen, 2005). Oleh karena itu, perbedaan antara varietas padi berperan penting dalam pelepasan $\mathrm{CH}_{4}$ dari lahan sawah.

$\mathrm{Ch}_{4}$ dihasilkan pada kondisi anaerobik. Mitigasi $\mathrm{CH}_{4}$ telah dipraktekkan di beberapa negara di Asia, diantaranya Jepang dan China. Teknik pengeringan " single mid - season drainage" selama 5-10 hari dapat mengurangi emisi $\mathrm{CH}_{4}$. Di dalam siklus alternate wetting and drying (AWD), air diirigasikan lagi agar tanah tergenang, setelah permukaan air turun di bawah permukaan tanah selama beberapa hari (berkisar 1 -10 hari) (Bouman dkk, 2007). Tujuan penelitian ini adalah untuk mengetahui pengaruh sistem pengelolaan air dan varietas padi terhadap hasil padi dan emisi GRK.

\section{METODE PENELITIAN}

Penelitian dilakukan di Kebun Percobaan Balingtan, Pati-Jawa Tengah pada bulan MaretJuni 2016. Penelitian menggunakan rancangan split plot dengan faktor I pengelolaan air (A1=Tergenang $5 \mathrm{~cm}$ dan $\mathrm{A} 2=$ Alternate Wetting and Drying/AWD), faktor II varietas padi $(\mathrm{V} 1=$ Ciherang, V2=Inpari $30, \mathrm{~V} 3=\mathrm{IPB} 3 \mathrm{~S})$, dan ulangan 3 kali. Ukuran petak percobaan $5 \mathrm{~m}$ x $6 \mathrm{~m}$ dengan usia tanaman 21 hari setelah sebar (HSS). Pengambilan sampel gas rumah kaca (GRK) dilakukan seminggu sekali dengan menggunakan boks $\mathrm{CH}_{4}$ ukuran $50 \mathrm{~cm} \times 50 \mathrm{~cm}$ x $100 \mathrm{~cm}$ dan boks $\mathrm{N}_{2} \mathrm{O}$ ukuran $20 \mathrm{~cm}$ x $40 \mathrm{~cm}$ x $30 \mathrm{~cm}$.

Pemupukan dilakukan dengan pemberian pupuk kompos kotoran sapi dengan takaran 3 ton/ha yang diberikan pada saat pengolahan tanah. Pemupukan tanaman terdiri dari pupuk

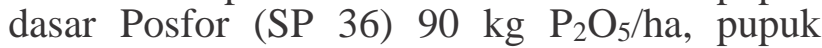
Nitrogen (Urea) $120 \mathrm{~kg}$ N/ha dan pupuk Kalium (KCl) $90 \mathrm{~kg} \mathrm{~K} 2 \mathrm{O} / \mathrm{ha}$. Pemupukkan $\mathrm{N}$ pertama sebesar $1 / 4$ dosis $(30 \mathrm{~kg} \mathrm{~N} / \mathrm{ha})$ dan selanjutnya diberikan berdasarkan Bagan Warna Daun (BWD) yang disesuaikan dengan kebutuhan tanaman. Data yang diamati terdiri dari (1) fluks $\mathrm{CH}_{4}$ dan $\mathrm{N}_{2} \mathrm{O}$ (2) tinggi tanaman dan jumlah anakan, (3) pH dan Eh tanah, (4) hasil gabah.

Pengukuran gas rumah kaca dilakukan dengan metode sungkup tertutup ( close chamber). Sampel gas $\mathrm{CH}_{4}$ diambil dengan menggunakan jarum suntik volume $10 \mathrm{ml}$ dengan interval waktu pengambilan setiap menit ke-5, 10, 15, 20 dan 25, sedangkan untuk gas $\mathrm{N}_{2} \mathrm{O}$ diambil pada interval menit ke-10, 20, 30, 40 dan

50. Analisis gas dilakukan di Lab Gas Rumah Kaca Balingtan, Pati. Konsentrasi gas $\mathrm{CH}_{4}$ dalam setiap satuan waktu dianalisa menggunakan kromatografi gas Shimadzu 14A yang dilengkapi dengan detektor FID ( Flame Ionization Detector), sedangkan konsentrasi gas $\mathrm{CH}_{4}$ dianalisa dengan menggunakan kromatografi gas Shimadzu 14A yang dilengkapi detektor ECD (Electron Capture Detector).

\section{HASIL DAN PEMBAHASAN}

\section{Emisi Gas $\mathrm{CH}_{4}$}

Pengukuran fluks $\mathrm{CH}_{4}$ menunjukkan bahwa semua perlakuan mempunyai pola yang mirip. Pada awal pertumbuhan tanaman sangat rendah kemudian mulai meningkat secara cepat pada fase anakan aktif (Gambar 1). Fluks $\mathrm{CH}_{4}$ pada semua perlakuan mencapai puncaknya ada saat memasuki fase pembentukan primordia bunga dan kemudian mulai menurun pada fase 
pemasakan biji. Perlakuan A1V1 dan A1V3 menunjukkan kenaikan fluks pada akhir pengamatan. Fenomena tersebut mungkin disebabkan karena adanya tahap pengeringan sebelum panen sehingga $\mathrm{CH}_{4}$ yang terperangkap dalam pori-pori tanah keluar. Pada Gambar 2 tampak jelas bahwa kumulatif fluks $\mathrm{CH}_{4}$ tertinggi terdapat pada perlakuan A1V3, kemudian diikuti oleh perlakuan A1V2, A1V1, A2V3, A2V2 dan A2V1. Hal ini menunjukkan bahwa perlakuan AWD dapat menghasilkan fluks $\mathrm{CH}_{4}$ yang lebih rendah dibandingkan perlakuan tergenang pada semua varietas padi. Dinamika fluks $\mathrm{CH}_{4}$ sangat dipengaruhi oleh kondisi air.

Masing-masing varietas berpengaruh terhadap fluks $\mathrm{CH}_{4}$ karena perbedaan jumlah dan jenis eksudat akar (glukosa dan asam asetat) (Lu $d k k$, 2000). Eksudat akar mudah terdekomposisi dan cepat digunakan sebagai substrat yang penting bagi metanogen (Christensen dkk, 2003). Eksudat akar berpengaruh lebih dari separuh fluks $\mathrm{CH}_{4}$ dari tanaman padi. Disamping berbeda jenis dan jumlahnya antar varietas, eksudat akar juga tergantung pada tahap pertumbuhan tanaman (Aulakh $d k k, 2001$ ).

Emisi $\mathrm{CH}_{4}$ dari perlakuan air dan varietas padi berkisar antara 94-194 kg/ha. Emisi $\mathrm{CH}_{4}$ tertinggi terdapat pada perlakuan A1V3, kemudian diikuti A1V2, A1V1, A2V3, A2V2 dan A2V1 secara berturut-turut (Gambar 3). Pada varietas Ciherang, Inpari 30 dan IPB3S, perlakuan AWD menurunkan emisi $\mathrm{CH}_{4}$ berturut-turut sebesar 43\%, 47\% dan 30\%. Perlakuan AWD menurunkan emisi $\mathrm{CH}_{4}$ secara signifikan.

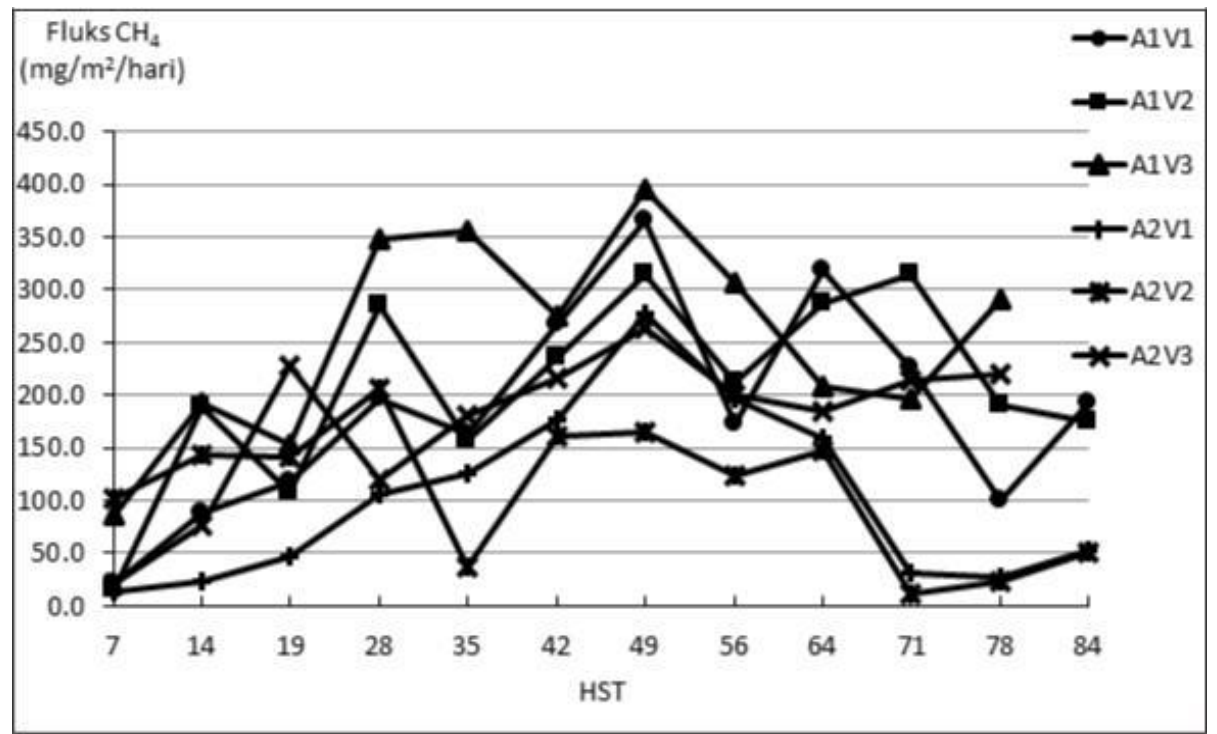

Gambar 1. Pola fluks $\mathrm{CH}_{4}$ pada berbagai perlakuan air dan varietas padi

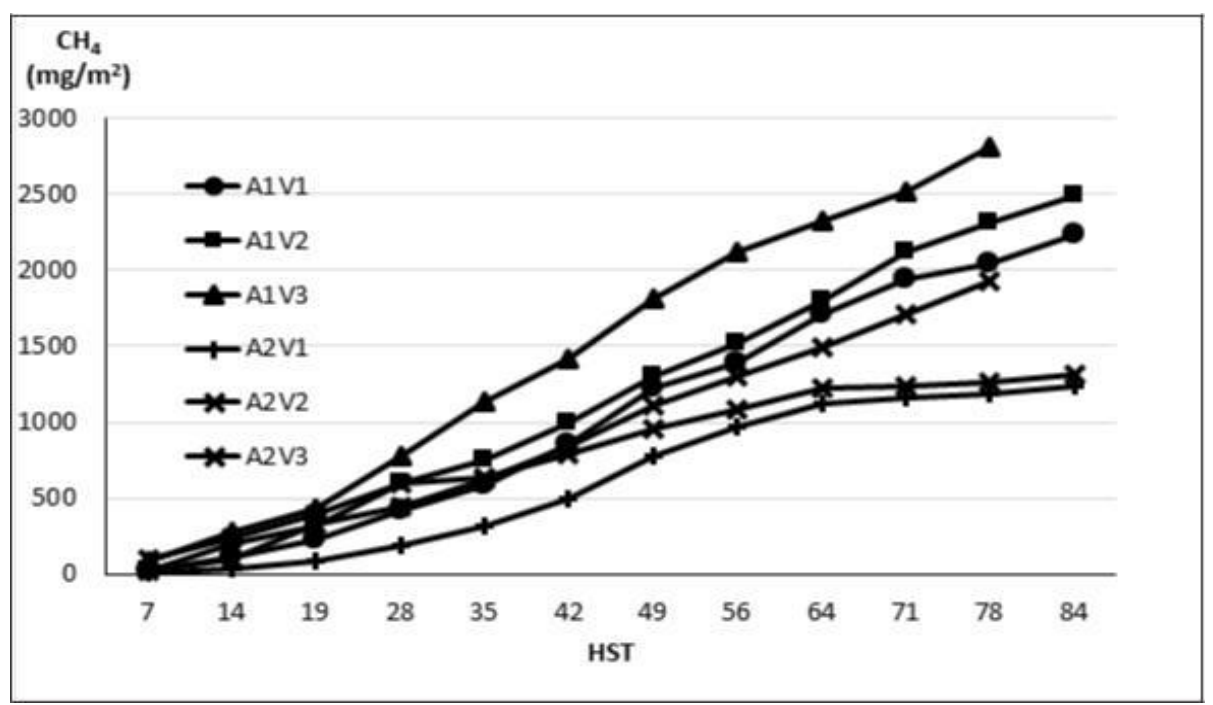

Gambar 2. Kumulatif fluks $\mathrm{CH}_{4}$ pada berbagai perlakuan pengelolaan air dan varietas padi 


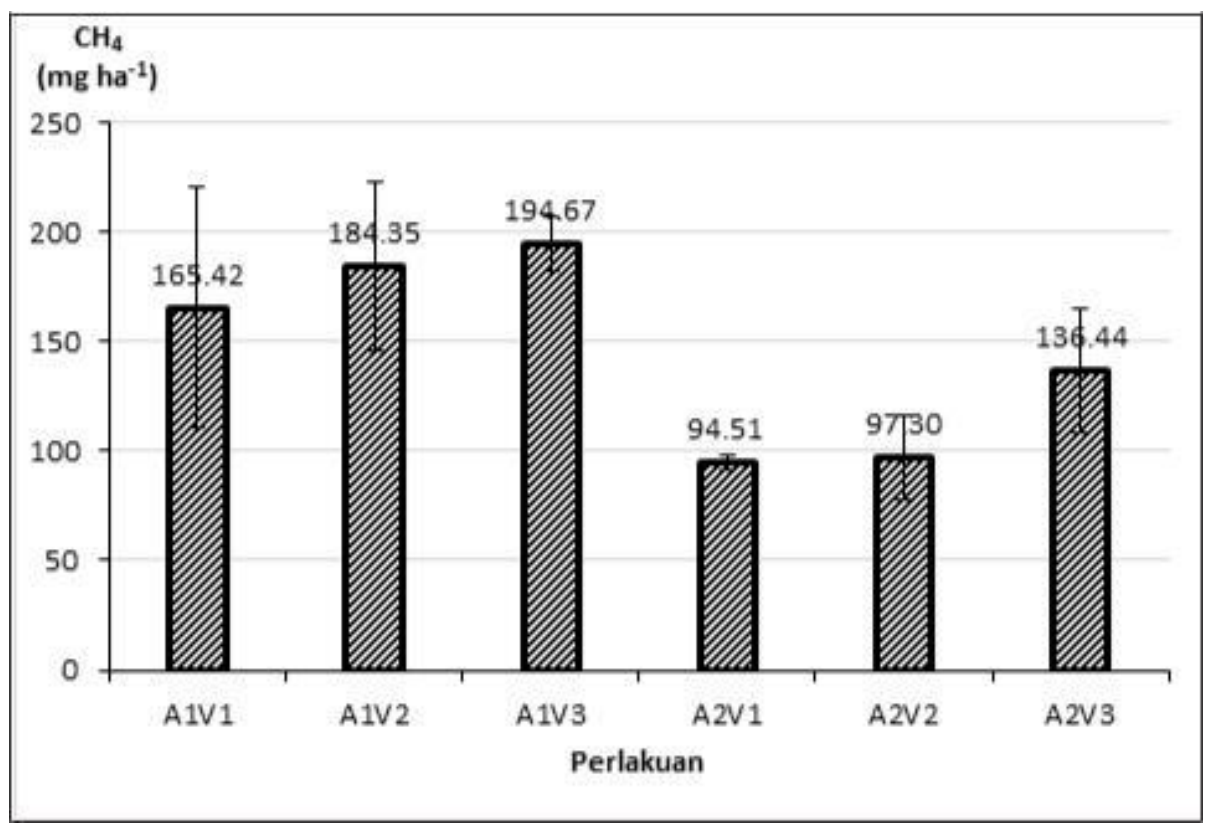

Gambar 3. Emisi $\mathrm{CH}_{4}$ dari perlakuan air dan varietas padi

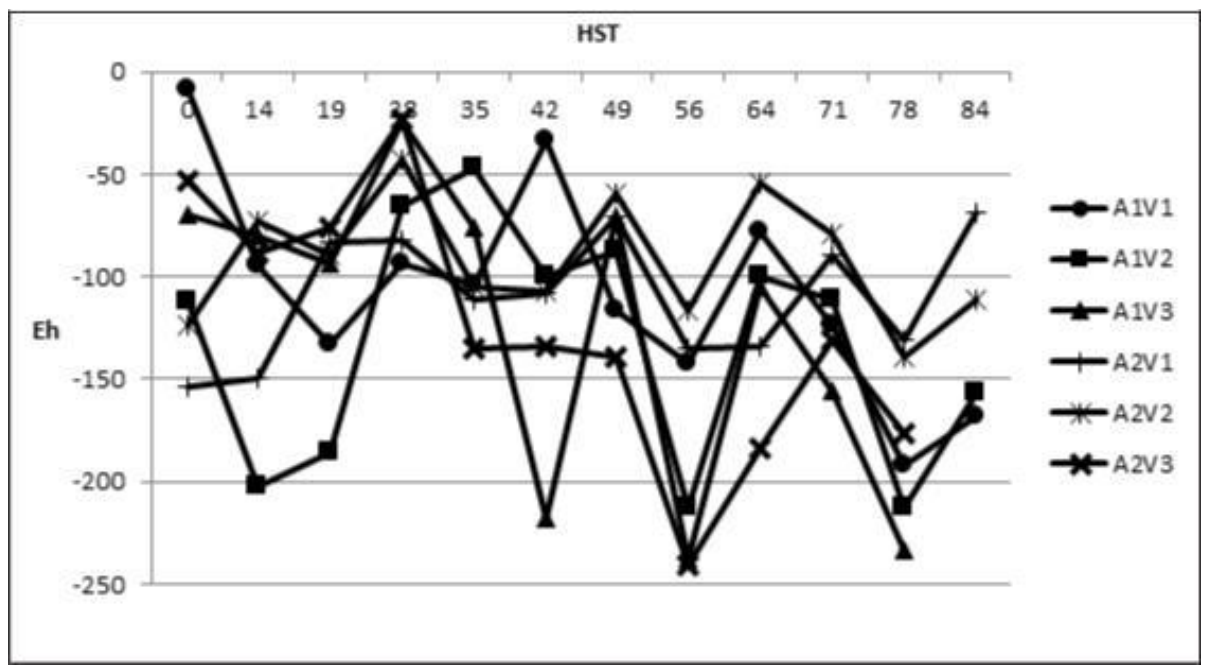

Gambar 4. Pengamatan Eh pada berbagai perlakuan air dan varietas padi Walik Jerami 2016

Lee dkk, (2012) melaporkan bahwa pengeringan di tengah masa tanam (midterm drainage) pada tahap anakan maksimum mengurangi emisi $\mathrm{CH}_{4}$ sebesar $43,8 \%$, dibandingkan pengairan tergenang. Fluks $\mathrm{CH}_{4}$ tertinggi pada semua perlakuan terdapat pada fase awal primordia, hal ini didukung oleh hasil pengamatan $\mathrm{Eh}$ dan $\mathrm{pH}$ (Gambar 4 dan Gambar 5). Penurunan pH dan Eh tanah selama pertumbuhan tanaman mungkin disebabkan karena tanaman mengeluarkan eksudat akar maksimum. $\mathrm{pH}$ tanah yang mencapai 5,6 dan Eh berkisar -200mV merupa-kan kondisi ideal bagi pertumbuhan metanogen. Penurunan $\mathrm{pH}$ kemudian diikuti dengan pemberian pupuk $\mathrm{N}$ menyebabkan potensial redoks (Eh) menurun dan ini akan menstimulasi metanogen (Wang dkk, 1992).

Hasil pengamatan terhadap tinggi air permukaan pada perlakuan tergenang dan perlakuan AWD dengan berbagai varietas padi terdapat pada Gambar 6 dan Gambar 7. Tampak pada perlakuan AWD dengan berbagai varietas padi menunjukkan terdapat 4 kali fase penurunan air permukaan. Dengan adanya kondisi rizosfer yang basah dan kering silih berganti, menyebabkan kondisi aerob, sehingga dapat menyebabkan turunnya fluks $\mathrm{CH}_{4}$ pada semua varietas padi. 


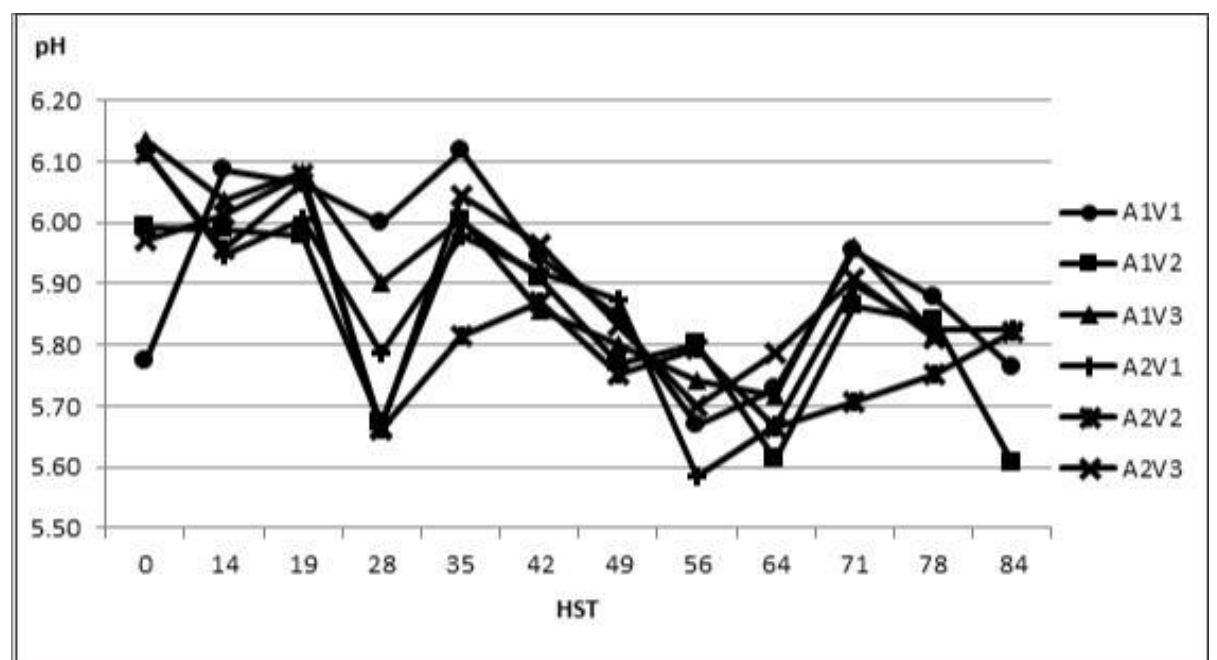

Gambar 5. Pengamatan Eh pada berbagai perlakuan air dan varietas padi

Walik Jerami 2016

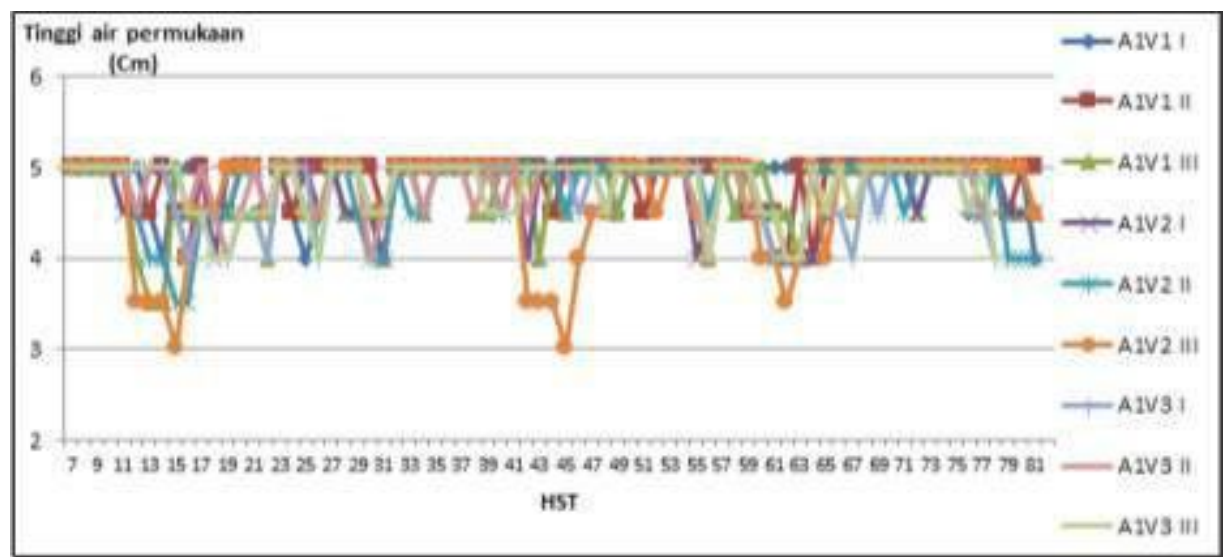

Gambar 6. Pengamatan PH pada berbagai perlakuan air dan varietas padi

Walik Jerami 2016

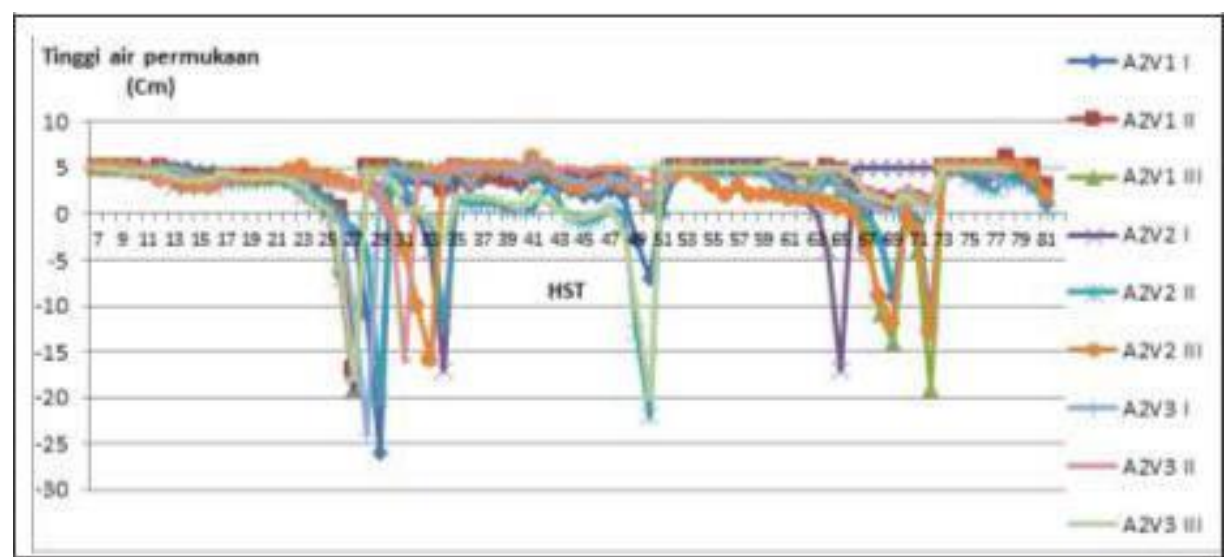

Gambar 7. Pengamatan tinggi air permukaan pada perlakuan pengairan tergenang dengan berbagai varietas padi Walik Jerami 2016

\section{Emisi Gas $\mathrm{N}_{2} \mathrm{O}$}

Gambar 8. menunjukkan bahwa pemupukan anorganik mempengaruhi pola fluks $\mathrm{N}_{2} \mathrm{O}$. Mishra dkk, (2012) menyatakan bahwa apikasi pemupukan berhubungan erat dengan emisi $\mathrm{N}_{2} \mathrm{O}$. Pemupukan anorganik yang dilakukan pada fase anakan aktif (7 HST), fase anakan maksimum (21 HST) dan fase primordia (42 HST) menyebabkan kenaikan fluks $\mathrm{N}_{2} \mathrm{O}$. Kumulatif fluks $\mathrm{N}_{2} \mathrm{O}$ yang terlihat pada Gambar 9, menunjukkan bahwa kumulatif fluks tertinggi terdapat pada perlakuan $\mathrm{A} 1 \mathrm{~V} 1$. Emisi $\mathrm{N}_{2} \mathrm{O}$ tertinggi pada perlakuan $\mathrm{A} 2 \mathrm{~V} 2$ 
(Gambar 10), karena periode basah kering pada perlakuan AWD menyebabkan kondisi aerob dan aerobik silih berganti sehingga sangat cocok untuk proses nitrifikasi dan denitrifikasi. Perlakuan air dan varietas padi memberi-kan emisi GRK yang sangat bervariasi, emisi tertinggi

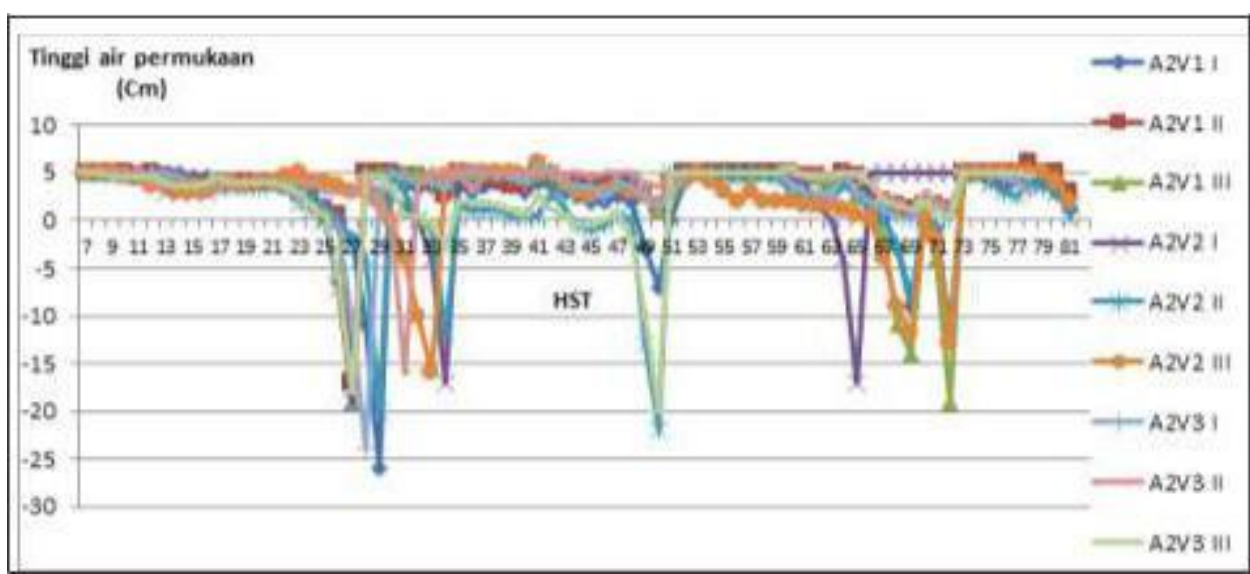

Gambar 8. Pengamatan tinggi air permukaan pada perlakuan pengairan

AWD dengan berbagai varietas padi Walik Jerami 2016

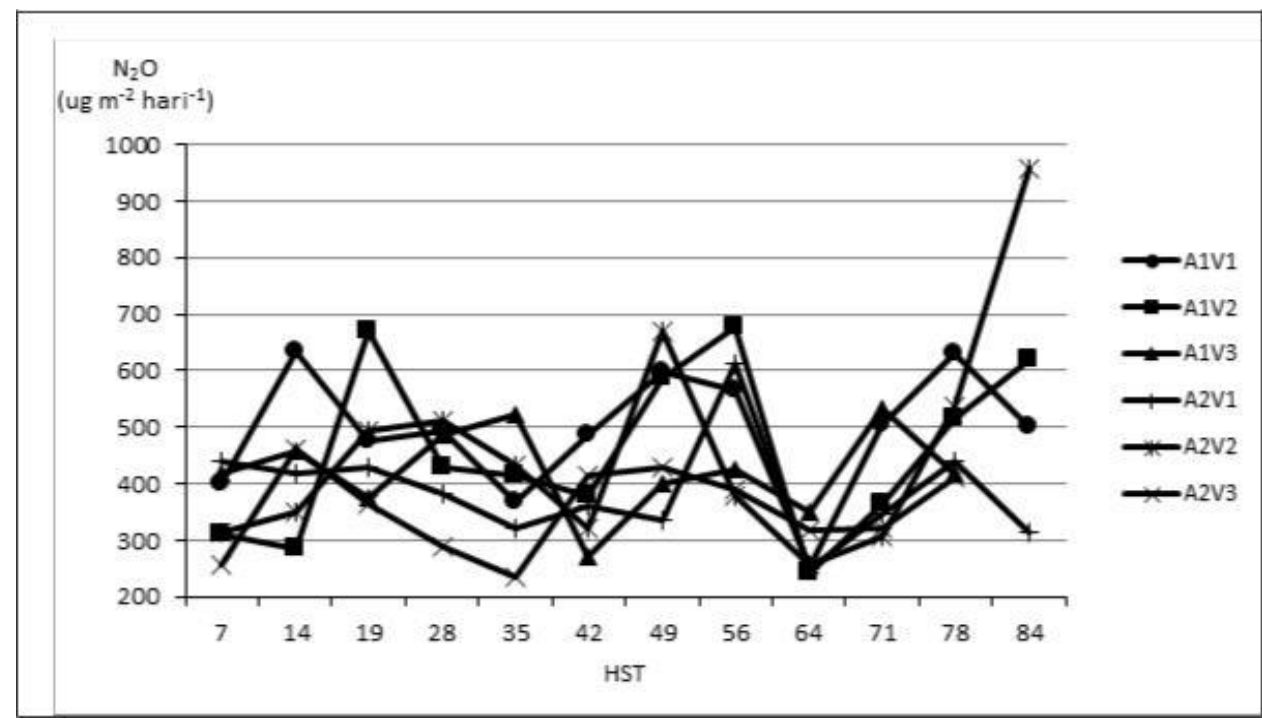

Gambar 9. Pola fluks $\mathrm{N}_{2} \mathrm{O}$ pada berbagai perlakuan air dan varietas padi

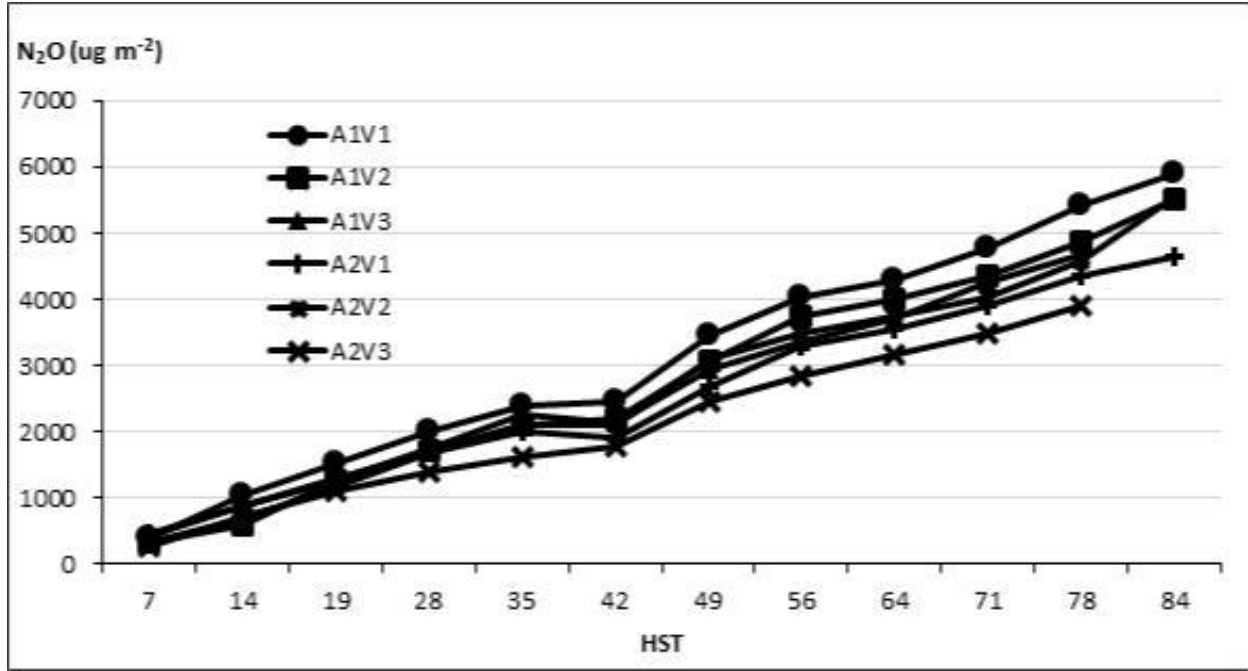

Gambar 10. Kumulatif fluks $\mathrm{N}_{2} \mathrm{O}$ pada berbagai perlakuan pengelolaan air dan varietas padi 
terdapat pada perlakuan A1V2 (Gambar 11), dimana pada kondisi tergenang dengan menanam varietas Inpari 30 menyebabkan emisi $\mathrm{CO}_{2}$-e sebesar 5 ton $\mathrm{ha}^{-1}$. Emisi GRK terendah terdapat pada perlakuan A2V2 (AWD dengan varietas Inpari 30) yaitu sebesar 2,6 ton $\mathrm{ha}^{-1}$. Karena emisi $\mathrm{N}_{2} \mathrm{O}$ dari semua perlakuan relatif kecil, emisi GRK dipengaruhi sangat besar oleh emisi $\mathrm{CH}_{4}$. Besarnya penurunan emisi GRK dari perlakuan AWD dengan varietas Ciherang, Inpari 30 dan IPB3S masing-masing sebsar $42 \%$, 46\% dan 30\%. Varietas padi Ciherang mengemisi paling rendah dibandingkan varietas Inpari 30 dan IPB3S, baik pada perlakuan tergenang maupun AWD.

\section{Parameter Tanaman}

Hasil pengukuran tinggi tanaman dan jumlah anakan pada masing-masing berbagai perlakuan air dan varietas padi MT Walik Jerami 2016 terdapat pada Gambar 12 dan 13. Varietas padi IPB3S mempunyai perawakan tinggi, namun jumlah anakannya relatif paling sedikit. Tinggi tanaman IPB3S mencapai $110 \mathrm{~cm}$, sedangkan Ciherang dan Inpari 30 hanya $90-95 \mathrm{~cm}$. Jumlah anakan padi IPB3S berkisar 7, sedangkan Ciherang dan Inpari 30 mempunyai anakan 8-9. Meskipun mempunyai anakan paling sedikit, IPB3S mengemisi $\mathrm{CH}_{4}$ tertinggi baik pada perlakuan tergenang maupun AWD. Umur tanaman juga lebih pendek dibandingkan varietas

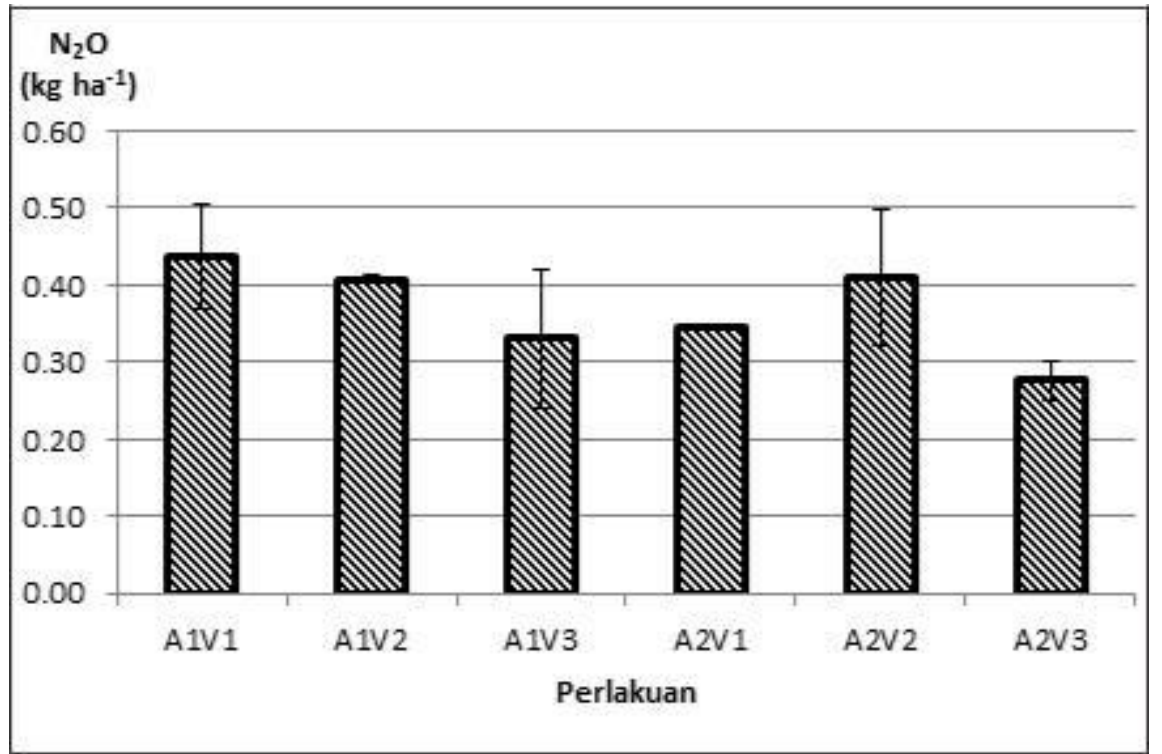

Gambar 11. Emisi $\mathrm{N}_{2} \mathrm{O}$ pada perlakuan air dan varietas padi

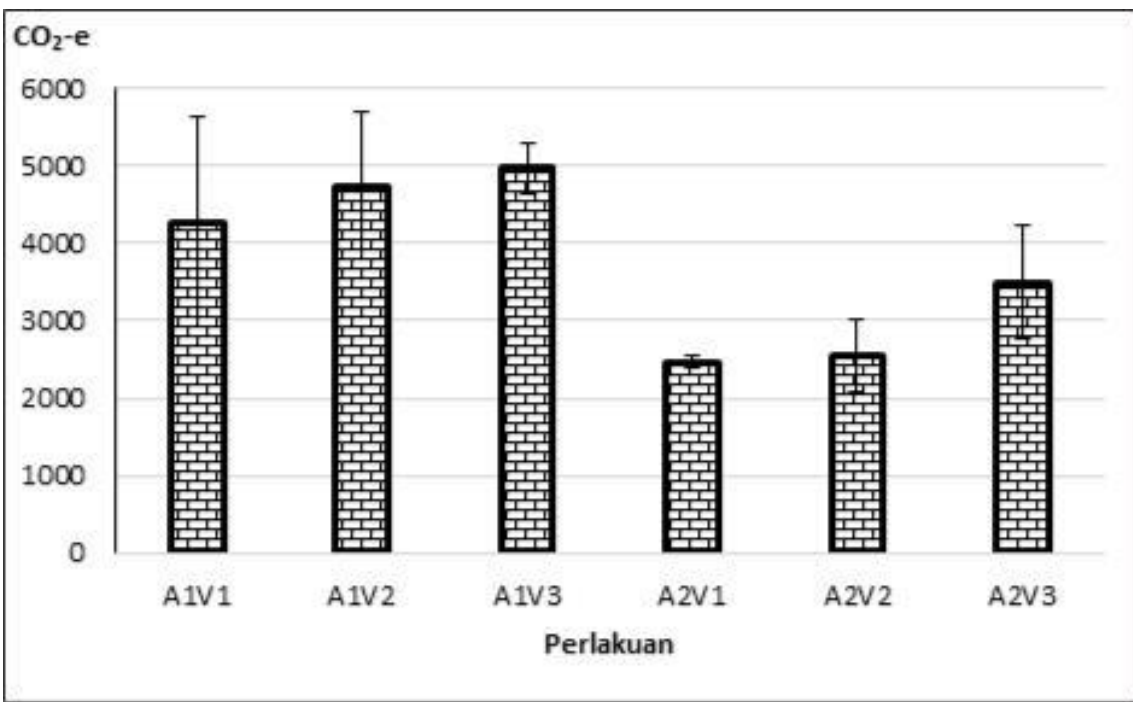

Gambar 12. Emisi GRK $\left(\mathrm{CO}_{2}\right.$-e) pada perlakuan air dan varietas padi 
Ciherang dan Inpari 30. Hal ini diduga bahwa padi IPB3S mengeluarkan eksudat akar lebih banyak jumlah dan jenisnya untuk mendukung pertumbuhan metanogen.

\section{Hasil Gabah}

Gambar 14 menunjukkan hasil GKG yang diperoleh dari masing-masing perlakuan. Hasil gabah tertinggi terdapat pada perlakuan A1V1 yaitu sebesar 3,26 ton ha- ${ }^{-1}$ namun tidak berbeda nyata dengan perlakuan yang lain. Hasil padi ratarata di lahan tadah hujan pada penelitian ini tergolong rendah, hal ini karena adanya serangan hama walang sangit yang cukup intensif sehingga persentase gabah isinya relatif rendah (Tabel 1). Indeks emisi, yaitu perbandingan antara emisi dengan hasil gabah terkecil dalam penelitian ini adalah perlakuan A2V2, diikuti oleh A2V1, A2V3, A1V1, A1V3, A1V2, masing- masing sebesar 0,$78 ; 0,80 ; 1,12 ; 1,33 ; 1,59 ;$ dan 1,60 . Semakin kecil indeks emisi berarti semakin kecil GRK yang diemisikan untuk menghasilkan persatuan berat gabah.

Pada saat ini AWD diaplikasikan dengan berbagai metode. AWD dapat diintegrasikan dengan metode budidaya padi konvensional dan SRI, dimana AWD adalah komponen intinya. Banyak peneliti menyatakan bahwa AWD dapat mengurangi kebutuhan air. Namun, dampak penerapan AWD terhadap produktivitas padi berbeda-beda. Meskipun produktivitas air meningkat, produksi padi bisa menurun bahkan sama dibandingkan dengan pengairan tergenang. Bouman dan Tuong (2001), menyatakan bahwa

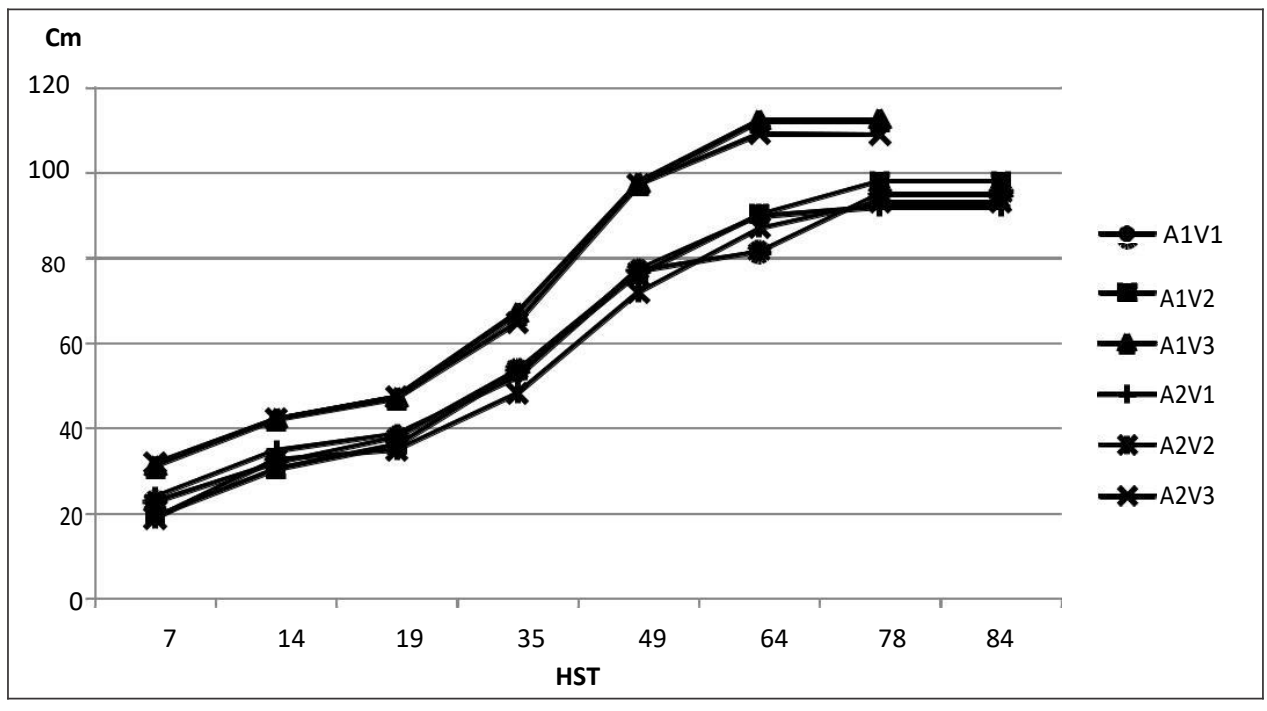

Gambar 13. Tinggi tanaman pada berbagai perlakuan air dan varietas padi, Walik Jerami 2016

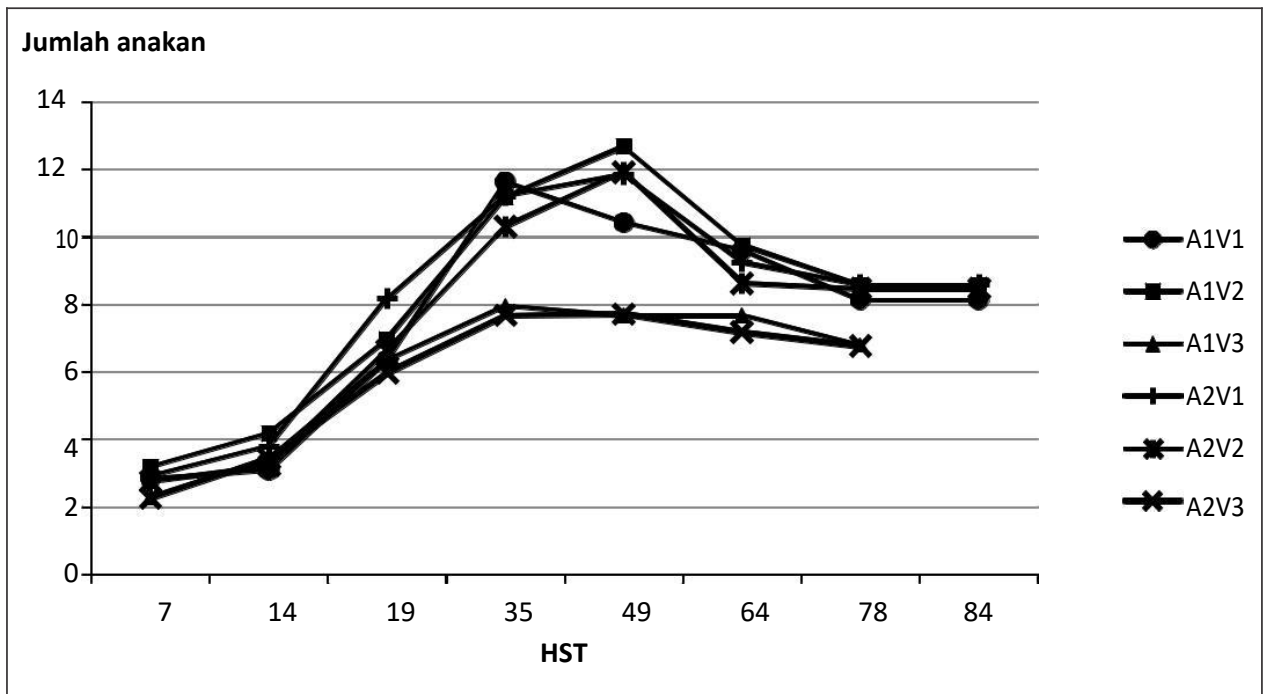

Gambar 14. Jumlah anakan pada berbagai perlakuan air dan varietas padi, Walik Jerami 2016 
92\% perlakuan AWD menyebabkan penurunan produksi sebesar 0\% hingga 70\% dibandingkan plot control (tergenang). Penelitian Yao et al. (2012) yang menggunakan varietas padi "super hybrid" dan varietas toleran kekeringan memberikan hasil efisiensi sebesar 24\%-38\% namun tidak berbeda hasil gabahnya dengan perlakuan AWD.

Hasil gabah dan komponen hasil tertera pada Tabel 1. Tampak bahwa berat 1000 butir gabah pada varietas IPB3S paling tinggi, namun
\% gabah isinya paling rendah, kemudian diikuti Inpari 30 dan Ciherang. Berat kering biomas atas dan akar tertinggi terdapat pada perlakuan A2V3 (AWD dengan varietas padi IPB3S) yaitu sebesar 5,7 gram berat kering per rumpun, terendah pada varietas Inpari 30 yaitu sebesar 2,7 gram berat kering per rumpun. Hal ini berarti bahwa berat akar berpengaruh signifikan terhadap emisi $\mathrm{Ch}_{4}$.

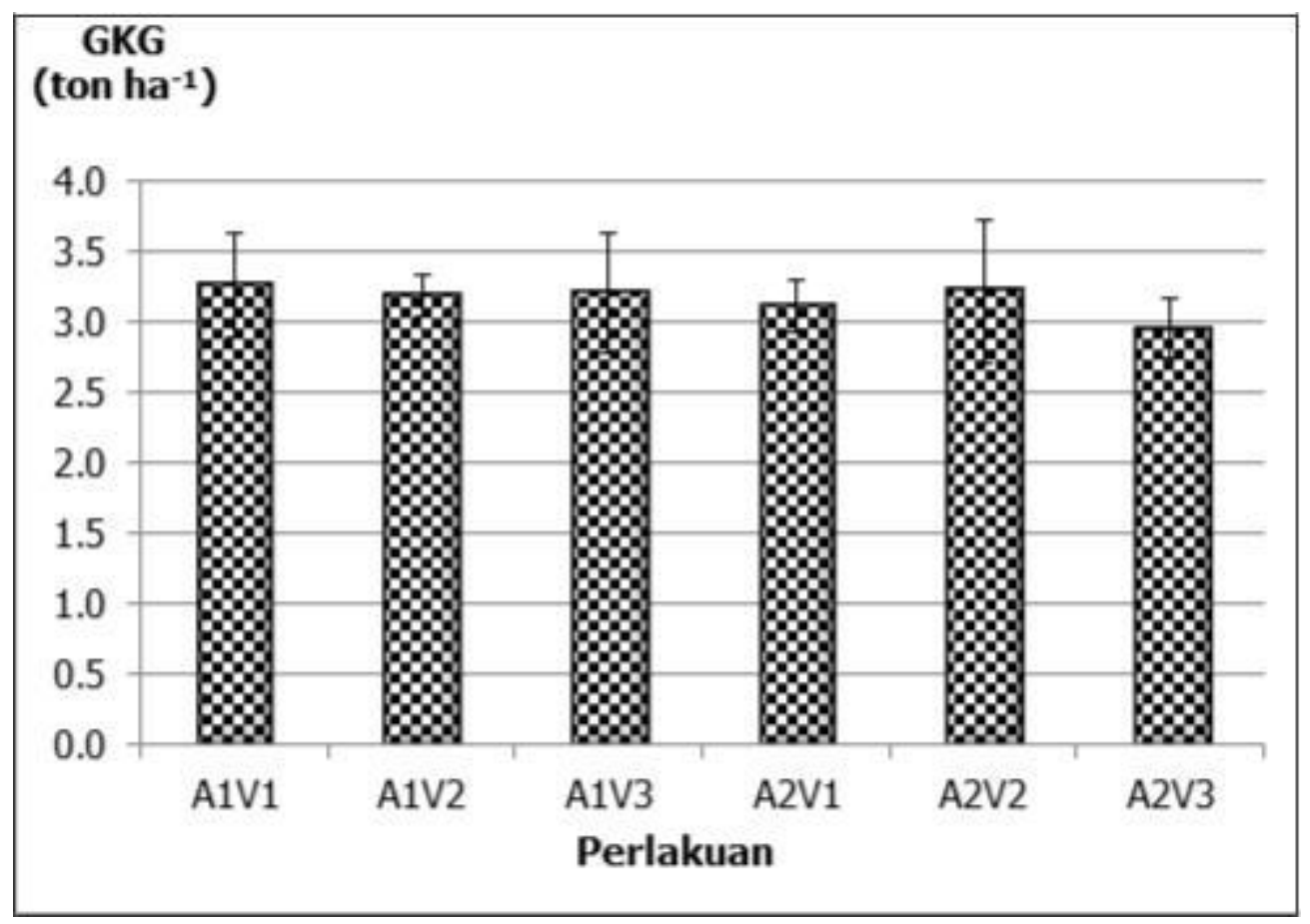

Gambar 15. Hasil gabah dari perlakuan air dan varietas

Tabel 1. Hasil dan komponen hasil dari perlakuan air dan varietas padi

\begin{tabular}{lcccccc}
\hline Perlakuan & $\begin{array}{c}\text { GKG } \\
\text { ton/ha) }\end{array}$ & $\begin{array}{c}\text { Berat 1000 } \\
\text { butir }(\mathrm{g})\end{array}$ & $\begin{array}{c}\text { \% gabah } \\
\text { isi }\end{array}$ & $\begin{array}{c}\text { Berat biomas } \\
\text { atas }(\mathrm{g})\end{array}$ & $\begin{array}{c}\text { Berat akar } \\
(\mathrm{g})\end{array}$ \\
\hline A1V1 & $3.3 \mathrm{a}$ & & $25.3 \mathrm{c}$ & $62.5 \mathrm{ab}$ & $16.8 \mathrm{a}$ & $2.8 \mathrm{~b}$ \\
$\mathrm{~A} 1 \mathrm{n} 2$ & $3.2 \mathrm{a}$ & $27.1 \mathrm{ab}$ & $68.6 \mathrm{a}$ & $18.5 \mathrm{a}$ & $2.6 \mathrm{~b}$ \\
$\mathrm{~A} 1 \mathrm{a} 3$ & $3.2 \mathrm{a}$ & $28.1 \mathrm{a}$ & $60.7 \mathrm{ab}$ & $17.6 \mathrm{a}$ & $4.3 \mathrm{ab}$ \\
$\mathrm{A} 2 \mathrm{~V} 1$ & $3.1 \mathrm{a}$ & $26.3 \mathrm{bc}$ & $64.8 \mathrm{ab}$ & $15.9 \mathrm{a}$ & $2.7 \mathrm{~b}$ \\
A2V2 & $3.2 \mathrm{a}$ & $27.2 \mathrm{ab}$ & $66.2 \mathrm{ab}$ & $17.3 \mathrm{a}$ & $2.4 \mathrm{~b}$ \\
A2V3 & $3.0 \mathrm{a}$ & $27.7 \mathrm{a}$ & $58.3 \mathrm{~b}$ & $19.7 \mathrm{a}$ & $5.7 \mathrm{a}$ \\
\hline
\end{tabular}

\section{KESIMPULAN}

Hasil penelitian ini menunjukkan bahwa

1. Hasil padi tertinggi terdapat pada perlakuan A2V1 (AWD dengan varietas Ciherang) sebesar 3,26 ton GKG/ha.

2. Emisi $\mathrm{CH}_{4}$ terendah dihasilkan pada perla- kuan A2V1 (AWD dengan varietas padi Ciherang).

3. Emisi $\mathrm{N}_{2} \mathrm{O}$ terendah dihasilkan pada perlakuan A2V3 (AWD dengan varietas IPB3S).

4. Emisi GRK tertinggi terdapat pada perlakuan A1V3 (tergenang dengan varietas IPB3S). Emisi GRK terendah terdapat pada A2V1 (perlakuan AWD dengan varietas Ciherang. 
5. Indeks emisi terendah terdapat pada perlakuan A2V2 (perlakuan AWD dengan varietas Inpari 30).

6. Perlakuan AWD dapat menurunkan emisi GRK pada varietas padi Ciherang, Inpari 30 dan IPB3S masing-masing sebesar 42\%, $46 \%$, dan $30 \%$ dibandingkan dengan kondisi tergenang.

\section{DAFTAR PUSTAKA}

Aulakh, M.S., Bodenmender, J., Wassmann, R., Rennenberg, H., 2000. Methane transport capacity of rice plants. Part II. Variations among different rice cultivars and relationship with morphological charac-teristics. Nutr. Cycl. Agroecosyst. 58, 367-375

Aulakh MS, Wassmann R, Bueno C, Kreuzwieser J and Rennenberg, H. 2001. Characterization of root exudates at different growth stages of ten rice (Oryza sativa L.) cultivars. Plant Biology 3: 139-149.

Bodelier, P.L., Roslev, P., Henckel, T., Frenzel, P., 2000. Stimulation by ammonium based fertilizers of methane oxidation in soil around roots. Nature 403, 421-424. Butterbach Bahl , K ., Papen, H., Rennenberg, H., 1997. Impact of gas transportthrough rice cultivars on methane emission in rice paddy fields. Plant Cell Environ. 20, 1175-1183.

Bouman, B.A.M. and Tuong, T.P. 2001. Field water management to save water and increase its productivity in irrigated $1 \mathrm{o} \mathrm{W}$ land rice. Agricultural Water Management 49: 11-30.

Denman, K.L., Brasseur, G., Chidthaisong, A., Ciais, P., Cox, P.M., Dickinson, R.E., Hauglustaine, D., Heinze, C., Holland, E., Jacob, D., Lohmann, U., Ramachadran, S., da Silva Dias, P.C., Wofsy, S.C., Zhang, X., 2007. Coupling between changes in the climate system and biogeochemistry. Climate change 2007: The physical science basis. In: Soloma, S., Ain, D., Manning, M., Chen, Z., Marquis, M., Averyt, K.B., Tignon , M ., Miller, H . L. ( Eds. ), Contribution of working Group I to the Fourth Assessment Report of the Intergovernmental Panel on Climate Change. Cambridge University Press, Cambridge, UK and New York, NY, pp. 499-587.

Dubey, S.K. 2005. Microbial ecology of methane emission in rice agroecosystem: a review. Applied Ecology and Environmental Research 3(2), 1-27.

IPCC, 2007. Summary for policymakers. In: Climate change 2007: The physical science basis. Contribution of Working Group 1 to the Fourth Assessment Report of the Intergovernmental Panel on Climate Change. Cambridge University Press, Cambridge, United Kingdom and New York, NY, USA.
Kerdchoechuen, O., 2005. Methane emission in four rice varieties as related to sugars and organic acids of roots and root exudates and biomass yield. Agric. Ecosyst. Environ. 108, 155-163

Lee DB, Jung SC, So KH, Jeong JW, Jung HC, Kim GY, Shim KM. 2012. Evaluation of mitigation technologies and footprint of carbon in unhulled rice production. Climate Change Res. 3: 129-142

Lu L, Wassmann R, Neue HU, Huang C and Bueno CS. 2000. Methanogenic responses to exogenous substrates in anaerobic rice. Soil Biology and Biochemistry 32: 1 683-1 690.

Christensen TR, Panikov N, Mastepanov M, Joabsson A, Steward A, Öquist M, Sommerkorn M, Reynaud S and Svensson B. 2003. Biotic controls on $\mathrm{CO} 2$ and $\mathrm{CH} 4$ exchange in wetlands aclosed environment study. Biogeochemistry 64: 337-354.

Mishra SN, S Mitra, L Rangan, S Dutta and P Singh. 2012. Exploration of 'hot-spots' of methane and nitrous oxide emission from the agriculture fields of Assam, India. Agriculture \& Food Security $1: 16$

Wang, Z., Delaune, R.D., Lindau, C.W. W.H. Patrick Jr. 1992. Methane production from anaerobic soil amended with rice straw and nitrogen fertilizers. Fertilizer Research 33: doi:10.1007/BF01051166

Yao, F., Huang, J., Cui, K., Nie, L., Xiang, J., Liu, X., Wu, W., Chen, M. and Peng, S. 2012. Agronomic performance of high-yielding rice variety grown under alternate wetting and drying irrigation. Field Crops Research 126:16-22 